\title{
Development and supply strategy of cocoa commodity effect to cocoa farmers' revenue in Boalemo District
}

\author{
Abdurrahman Pakaya; Amir Halid*; Hermanto Payuyu \\ Agribusiness Study Department, Post Graduated Program, \\ Universitas Negeri Gorontalo, Indonesia \\ *To whom correspondence should be addressed.Email: amirhalid_ung@yahoo.com
}

\begin{abstract}
This study purpose to analyze the influence of development strategy and supply chain of cocoa commodity to cocoa farmer income. This research conducted in Boalemo District with research method using stratified random sampling technique with data analysis used is multiple linear regression analysis. The result of this research stated that partially cocoa commodity development strategy in Boalemo District give positive influence to farmer's income but has not give significant influence to farmer's income. Partially supply chain gives positive effect to cocoa farmer income in Boalemo District, beside giving positive influence, supply chain also give significant influence to cocoa farmer income in Boalemo District, and for dummy of influential sub-district that is Tilamuta sub-district, followed by Sub-district Dulupi and after that Botumoito District. Simultaneously, development strategies and supply chains have a positive and significant impact on cocoa farmers' income in Boalemo District.
\end{abstract}

Keywords: Development strategy, Supply chain, Income

JEL Classification: Q12, Q13, Q18

\section{INTRODUCTION}

Cocoa is one of agricultural products in Indonesia that potential to contribute country foreign exchange, at the world cocoa level of Indonesia keep up the third position after Ivory Coast and Ghana. This is supported by Indonesia's planting areas that are still widely available, labor and cocoa experts. It is not excessive if this potential can still be improved. Cocoa (Theobroma cocoa) is one of the agricultural products that have a real and reliable role in realizing agricultural development programs, especially in terms of employment, regional development, farmer livelihood improvement, and increased income / foreign exchange.

In Gorontalo Province cocoa commodity is one of the commodities that become the driving force of the farming economy. This can be seen from the ever-increasing rate of production which compares year by year. Based on data from the Directorate General of Estate Crops of the Ministry of Agriculture, cocoa production of Gorontalo in 2014 amounted to 2,890 (tons), in 2015 its production decreased to only 2,060 (ton), but in 2016 its production rose to 2,636 tons (Dispan Gorontalo Province, 2017).

Boalemo District through the Agriculture and Estate Crops Office has implemented the mission "Developing regional superior commodities based on the region for the welfare and improvement of regional economics in the form of Million Cocoa Commodity Movement Program. Development of Cocoa Commodity 
Commodity in Boalemo District is one of the efforts to increase farmer's income, improving the sustainability of agricultural land and increasing the production of export commodities. So from the side of sustainable agricultural business and the improvement of the regional economy becomes very important and strategic.

The One Million Cocoa Movement Program (GSK) is one of the flagship programs of Boalemo District launched in 2012 as an effort to realize independence and increase productivity of farmers through increasing the productivity of export commodities, especially cocoa for sustainable and sustainable agriculture development and increasing income and welfare.

The implementation of the One Million Cocoa Movement (GSK) Program in Boalemo District within 3 (Years) has been able to increase the cocoa plantation area from $2,832 \mathrm{Ha}$ in 2012 to $4,262.57 \mathrm{Ha}$ in 2014, the area of which is spread in seven sub districts in Paguyaman District 1,083.47 Ha; Wonosari 864.45 Ha, Mananggu 727 Ha, Dulupi $634 \mathrm{Ha}$, Botumoito $574 \mathrm{Ha}$, Paguyaman Coast 259.65 Ha and District Tilamuta $120 \mathrm{Ha}$ (Department of Agriculture and Plantation of Boalemo District).

The target of the Cocoa Million Movement (GSK) program which is the cocoa development strategy is for the fiscal year 2015 for the development of Kakao Sambung Pucuk totaling 288,129 trees consisting of the Boalemo District Budgets 238,129 trees (466 Ha) and the Budgets of Gorontalo Province amounting to 50,000 trees $(80 \mathrm{Ha}$ ). Activities financed through APBN TA. 2015 covering Rehabilitation of Cocoa Plants next to 300,000 trees and Intensification of Cocoa Garden area of $700 \mathrm{Ha}$ (Department of Agriculture and Plantation of Boalemo District).

In addition, the support for the provision of infrastructure through the local government budget (APBD in Indonesian) includes; 1200 pieces of cutting scissors, 300 buckwheel scissors, Hand Speyer 245, Hand electric spreyer 133 pieces, 15 grass trimmers, 2160 liters organic fertilizer and NPK $5000 \mathrm{Kg}$ fertilizer with total budget of GSK Program from APBD of Boalemo District Rp.4.866.707.700 and from State Budget (APBN in Indonesian) Rp.7.742.365.000 (Department of agriculture and plantation of Boalemo District).

For cocoa development area in Boalemo District based on cluster area consist of 9 clusters with potential area target of $8,560 \mathrm{Ha}$ Cocoa Cultivation and already cultivated cocoa area 4,262.57 Ha. These clusters are scattered in all sub-districts in Boalemo District. The Cocoa Development pattern involves the planting of Cocoa Sambung Pucuk monoculture system, cocoa planting of monoculture system is done on vacant land no other plantation cultivation, cultivation of cocoa shoots under the coconut tree, cultivation of Cakao Sambung Pucuk with Cengkih plant, Patchouli or Corn. Several other development strategies are cocoa farmers receiving technical guidance on integrated crop management and integrated pest management (Department of agriculture and plantation of Boalemo District).

Cocoa production in 2012 only reached 514.18 Ton, but in 2013 it jumped to 826.49 Ton. This production continues to increase in 2014 of 1,123.19 Ton, but in the Year 2015 production decreased, only 1,041,29 which is influenced by weather and pest attack. This production fluctuation certainly needs to be observed in order to improve the production and productivity improvement in supporting the welfare of cocoa farmers in Boalemo District (Department of Agriculture and Plantation Boalemo District). 
From the background above, the purposes of this research are 1) To analyze the effect of cocoa development strategy on cocoa farmer income in Boalemo District; 2) To analyze the effect of supply chain to cocoa farmer income in Boalemo District; 3) To analyze the influence of development strategy and supply chain income of cocoa farmers in Boalemo District, 4) To analyze the best in developing and increasing the income of cocoa farmers in Boalemo District.

\section{LITERATURE REVIEW}

Farmers face several challenges in agricultural supply chains in emerging economies that contribute to extreme levels of poverty. One common challenge is that farmers only have access to one channel, often an auction, for which to sell their crops. Recently, e-intermediaries have emerged as alternate, technology-driven posted-price channels. We aim to develop insights into the structural drivers of farmer and supply chain profitability in emerging markets and understand the impact of e-intermediaries. The develop an analytical model of a supply chain that allows us to study several key features of intermediated supply chains. We complement the model's insights with observations from a numerical study. The result in the absence of an e-intermediary, auctions cause farmers to either overproduce or underproduce compared to their ideal production levels in a vertically integrated chain. The presence of an e-intermediary with limited market share improves farmers' profits; however, if the e-intermediary grows too large, it nega tively impacts both farmers' and supply chain profits. Finally, as the number of farmers increases, farmers' profts approach zero, irrespective of the eintermediary's presence (Ferreiera, 2017).

This study analyses the short food supply chain as a competitive strategy for a multifunctional and multi-value farm, since it makes the citizen-consumer closer to the farm and the territory, creating welfare and shared value and increasing the farm and territory Reputation. This research focuses on the variables that influence the creation and sharing of value in the short food supply chain, with the aim to evaluate the impact of this strategy on the farm competitive repositioning The results of this study allow to identify those strategic variables that have a major impact on shared value creation, within the strategy of short food supply chain and the new model of multifunctional and multi-value farm, and to provide useful information for policy makers, emphasizing the need for public intervention and reform in the field, aimed, in particular, at encouraging the development of a young and educated human capital, a greater adhesion to networks and the production of localized public goods (Nazarro, 2016).

The growth of smallholder tobacco production since 2000 has been one of the big stories of Zimbabwe's post-land reform experience. Yet the implications for agrarian change, and the consequences for new relations between farmers, the state, and agribusiness capital have rarely been discussed. The paper reports on work carried out in the Mvurwi area of Mazowe district in Zimbabwe with a sample of 220 A1 (smallholder) farmers and 100 former farmworkers resident in compounds on the same farms. By going beyond a focus on operational and business dimensions of contract farming, the paper concludes with reflections on the implications for understanding agrarian relations and social differentiation in those areas of Zimbabwe where tobacco growing is now significant, with lessons more broadly on the political economy of 
contract farming, and the integration of agribusiness capital following land reform (Scoones, 2016).

Supply chain management can be defined as the integration of key business processes from end user to the original suppliers that provide products, services and information that add value for customers and stakeholders. The integration of all business processes with all stakeholders in the supply chain seems to make no sense apart from being, of course, a major waste of resources. In fact, in certain cases, the enormity of the task may make it impossible to overcome for a company whose supply chain presents a great complexity. Thus, it seems important that companies of all sizes find a way to manage more easily and effectively chains in which they operate. However, particularly in agricultural sector, integration of supply chain process has really brought significant impact on the efficiency of the overall procedures (Hussain, 2015).

This study examines the relationship between trade, investment and economic growth in India and China. The present study attempts to assess the contributions of not only foreign direct investment and exports as done by the previous studies but also incorporates domestic direct investment and imports. The study uses more comprehensive and recent autoregressive distributed lag (ARDL) bound testing approach to examine the existence of short-run and long-run relationships. The main advantage of this approach is that it can be used regardless of the stationarity properties of the variables in the sample. The study gives different results for both countries. In case of China, exports, FDI and domestic investment have positive impact on economic growth whereas for India only the variable of domestic investment has been found to be significant. China is a world leader in merchandise exports and its services exports have complemented its goods exports. The main weakness of Indian economy is the poor performance of manufacturing sector as a result of which India's merchandise exports are concentrated around a few categories. Though India is a leader in IT related services exports but these exports are unable to compensate for poor performance of merchandise exports (Malholtra, 2018).

Based on the previous study there are some key point of this research, the supply chain can be derived as the major of strategy to build an economic condition between farmer and the market to develop their profitability, there are some literature in this research:

Farmer Income is one of the main indicators to measure people's ability is to know the income level of the community. Revenue represents all money or other material achieved from the use of wealth or services received by a person or household for a certain period of time in an economic activity (Winardi, 1998). Every person who works wants maximum income or profit in order to meet the needs of his life. According Arsyad (2004), income is often used as an indicator of development of a country in addition to distinguish the level of economic progress between developed countries and developing countries. Revenue is a very important thing in determining the profit or loss of a business. Profit or loss is earned by comparing the income with expense or expenses incurred on the income.

Strategy definition is a way to achieve long-term goals. Business strategies may include geographical expansion, diversification, acquisition, product development, 
market penetration, employee rationalization, divestiture, liquidation and joint ventures (David, 2004).

The definition of strategy is a unified, broad and integrated plan that links the company's strategic advantage with environmental challenges, designed to ensure that the company's main objectives can be achieved through proper implementation by the organization (Glueck \& Jauch, 1989).

Strategy formulation is the process of preparing the step forward intended to build the vision and mission of the organization, set corporate strategic and financial goals, and design strategies to achieve these goals in order to provide the best customer value.Some steps that companies need to do in formulating strategies, namely: 1) Identify the environment that the company will enter in the future and determine the company's mission to achieve the desired vision in the environment; 2) Conduct an analysis of the internal and external environment to measure the strengths and weaknesses and opportunities and threats that will be faced by the company in carrying out its mission; 3) Formulate the key success factors of strategies designed based on prior analysis; 4) Determine measurable objectives and targets, evaluate alternative strategies by taking into account the resources it has and the external conditions it faces; 5) Choosing the most appropriate strategy to achieve short-term and long-term goals. (Dradjat, 2007).

Supply chain is a process process that starts from the collection of existing resources followed by management into finished products for subsequently distributed and marketed to end customers with regard to cost, quality, availability, after sales service, and reputation factor. The supply chain involves suppliers, manufacturers, and retailers synergistically and cooperate with each other directly or indirectly. (Wisner, Tan, and Leong, 2012).

A supply chain consists of all parties involved, directly or indirectly, in meeting customer demand. Supply chains include not only producers and suppliers, but also carriers, warehouses, retailers, and even customers themselves. From each organization, like a manufacturer, the supply chain covers all the functions involved in receiving and meeting customer demand. This function is comprehensive but not limited to new product development, marketing, operations, distribution, finance, and customer service (Chopra and Meindl, 2010). There is a close relationship between design and supply chain management (product, information, and funding) (Chopra and Meindl, 2010).

\section{METHODS}

This research conducted in Boalemo District, Gorontalo Province. The location was chosen because in general the farmers in the location mostly cultivated cocoa.

Research was designed as a survey study. The data used in research that is primary data and secondary data. Primary data were obtained from interviews and fizzy excision by farmers of cocoa farmers in Boalemo District. And secondary data is obtained from official reports from Gorontalo Central Bureau of Statistics, and other agencies that can assist in providing data.

The population in this study chose some districts of Botumoitu District, Tilamuta Subdistrict, and Dulupi Sub-district in Boalemo District which was determined by purposive sampling technique or intentionally because the five sub-districts have 
conducted initial survey so it is worthy to be established as research area. The total population in the five districts is 472 peoples.

Farmers respondent in this research done by random sampling with population reach by 472 rice farmer. One way to get a representative sample is by a process called random sampling. In relation to the size of the sample, Slovin proposed a formula for determining the size of the sample, thereby collecting 83 samples from 472 cocoa farmers.

In identifying problems 1 and 2, multiple linear regression analysis was used to find out the influence of cocoa farmer's development and supply chain strategy to cocoa farmer income in Boalemo District. With the following formula:

$$
Y=a+b_{1} X_{1}+b_{2} X_{2}+b_{3} D 1+b_{4} D 2
$$

$\mathrm{Y}=$ Income

$\mathrm{a}=$ Constant

$\mathrm{b}=$ Independent Variable Coefficient

$\mathrm{X}_{1}=$ Development Strategy

$\mathrm{X}_{2}=$ Supply Chain

$\mathrm{D}_{1}=$ Dummy Sub-District (1= Tilamuta, $0=$ other $)$

$\mathrm{D}_{2}=$ Dummy Sub-District (1= Dulupi, $0=$ other)

\section{RESULT AND DISCUSSION}

\section{Description of respondents characteristics}

Respondents in this study are farmers who members of farmer groups spread in Boalemo District with 83 people.

\section{Respondents characteristics by gender}

Gender is sexual identity in a person. It can be explained that the majority of respondents are male, that is 79 people or $95.2 \%$ while women are only 4 people or $4.8 \%$.

\section{Respondents characteristics by age}

Age is a long life of a farmer calculated by date of birth until the research is done. Based on research data in the field that age categopry still dominated by respondents aged 50-59 years with the number of 25 people or $30.1 \%$, then age $40-49$ years amounted to 22 people or $26.5 \%$, age $30-39$ years amounted to 17 people or $20.5 \%$, and who age 60 or older as many as 12 people or $14.5 \%$. While the number of respondents with age 20-29 years has the smallest number compared to other age categories that is $8.4 \%$, as in Table 1 .

Table 1. Respondents characteristics by age

\begin{tabular}{ccc}
\hline Age & Frequency & Percent \\
\hline $20-29$ & 7 & 8.4 \\
$30-39$ & 17 & 20.5 \\
$40-49$ & 22 & 26.5 \\
$50-59$ & 25 & 30.1 \\
60 or more & 12 & 14.5 \\
\hline Total & 83 & 100.0 \\
\hline
\end{tabular}

Source: Field Survey, 2017 


\section{Respondents characteristics by education level}

Education level is the level of education the last formal formal ever or being undertaken and educated nonformal ever followed. Level formal education is the level of education not the last one that has been and is followed by formal school. Level nonformal education is kind and the amount of training that has been followed by farmers in the past year. The level of formal education is measured by please educate the latest education farmers from the data in the field. Level formal education is distinguished in two categories, namely: level low formal education and level high formal education. Farmers with the last formal education level ( $\leq$ High School) categorized level of education formal "low". Farmers with levels formal education> High School) are categorized level of formal education "high".

Table 2. Respondents characteristics by education level

\begin{tabular}{lcc}
\hline Education Level & Frequency & Percent \\
\hline Elementary School & 27 & 32.5 \\
Junior High School & 16 & 19.3 \\
Senior High School & 11 & 13.3 \\
Diploma / Graduate & 3 & 3.6 \\
Not in School & 26 & 31.3 \\
\hline Total & $\mathbf{8 3}$ & $\mathbf{1 0 0 . 0}$ \\
\hline
\end{tabular}

Source: Field Survey, 2017

Based on the data in Table 2, showed that the low level of formal education is still highly visible in most respondents. Research respondents who have level of education only to elementary school graduate amounted to $32.5 \%$ and respondents who never received formal education amounted to $31.3 \%$. While the respondents with junior high school education category amounted to $19.3 \%$, and SLTA amounted to $13.3 \%$. The highest level of education up to the diploma / bachelor level is seen in a small percentage of respondents with only $3.6 \%$.

\section{The influence of cocoa farmer's development and supply chain strategy to cocoa farmer income in Boalemo District}

Multiple regression result showed in Table 3. Based on the result of multiple regression analysis interpretation below:

a. The constant of $-2,094(\alpha=-2,094)$

The value is a constant value of cocoa farmers' income in Boalemo District Gorontalo Province if there is no influence from Cocoa development strategy and Cocoa supply chain.

b. Regression coefficient X1 0,108 $(\beta 1=0,108)$

Coefficient of variable regression Cocoa development strategy showed that every improvement $(+)$ Strategy of cocoa development by 1 unit therefore Income of cocoa farmer of Boalemo District of Gorontalo Province will experience increase (+) equal to 0,108 unit with variable provision Cocoa supply chain in constant condition(cateris paribus).

c. Regression coefficient X2 0,307 ( $\beta 2=0,307)$

Variable regression coefficient The cocoa supply chain shows that each increase $(+)$ in the cocoa supply chain variables is 1 unit, the income of cocoa farmer of 
Boalemo District of Gorontalo Province will increase (+) by 0.307 units with the variable provisions Cocoa development strategy in constant condition(cateris paribus)

d. Dummy Interpretation

Based on the results of the analysis by adding dummy variables districts where for dummy 1 for District Tilamuta given point 1 and other districts given the 0 number then for dummy 2 for Dulupi District given point 1 and other districts are marked 0 . The analysis results show that the value of the constant is not significant shows that Botumoito District is not significant to cocoa farmer income then for Tilamuta and Dulupi sub-districts have a significant effect on farmer income cocoa.

Tabel 3. Regression model

\begin{tabular}{crrrrrr}
\hline \multirow{2}{*}{ Model } & \multicolumn{2}{c}{$\begin{array}{c}\text { Unstandardized } \\
\text { Coefficients }\end{array}$} & \multicolumn{2}{c}{$\begin{array}{c}\text { Standardized } \\
\text { Coefficients }\end{array}$} & \multirow{2}{*}{ t } & \multirow{2}{*}{ Sig. } \\
\cline { 2 - 3 } & \multicolumn{1}{c}{ B } & Std. Error & Beta & & \\
\hline Constant & $-2,094$ & 1,581 & & & $-1,324$ &, 189 \\
Cocoan Development Strategy &, 108 &, 038 &, 300 & & 2,850 &, 006 \\
Supply Chain &, 307 &, 073 &, 426 & & 4,217 &, 000 \\
Dummy 1 & 3,417 &, 614 &, 504 & & 5,568 &, 000 \\
Dummy 2 & 2,257 &, 798 &, 267 & & 2,829 &, 006 \\
\hline
\end{tabular}

$\mathrm{R}^{2}$ Test is used to know the influence of dependent and independent variable in this research from the total of influence of labor in family, labor outside family, land area and technology to rice production in Pohuwato, Gorontalo Province known from result of coefficient of determination $\left(\mathrm{R}^{2}\right)$ below :

Table 4. Coefficient of determination test result $\left(\mathrm{R}^{2}\right)$

\begin{tabular}{lcccc}
\hline Model & $\mathrm{R}$ & $\mathrm{R}$ Square & Adjusted R Square & Std. Error of the Estimate \\
\hline 1 &, $690^{\mathrm{a}}$ &, 476 &, 449 & 2,42995 \\
\hline
\end{tabular}

Based on the Table 4, then the value of determination coefficient adjusted R2 of 0.449 . This value means that as much as $44.9 \%$ of the income of cocoa farmers in Boalemo District, Gorontalo Province can be explained by the strategy of cocoa development and supply chain in Boalemo District, Gorontalo Province. While $55.1 \%$ is explained by other factors outside the model in the study. From these results can be seen that the addition of dummy variables in a district of this equation is very useful for the coefficient of determination so that variability variables seen from adjusted R2 has increased or the ability of independent variables in explaining the dependent variable there is an increase.

$F$ test is used to test the regression coefficients together to test the model that influences the relationship between the independent variable and the dependent variable. The test of significance of regression equation to be obtained is done by using $\mathrm{F}$ test. Together ( $\mathrm{F}$ test) between independent variables in this case between cocoa development strategy (X1), cocoa supply chain (X2), and income of cocoa farmer (Y). 
Table 5. Simultaneous test

\begin{tabular}{rlrrrrr}
\hline Model & & Sum of Squares & \multicolumn{1}{c}{ df } & Mean Square & F & \multicolumn{1}{c}{ Sig. } \\
\hline \multirow{3}{*}{1} & Regression & 418,643 & 4 & 104,661 & 17,725 &, $000^{\mathrm{b}}$ \\
& Residual & 460,562 & 78 & 5,905 & & \\
& Total & 879,206 & 82 & & & \\
\hline
\end{tabular}

Based on the analysis results in Table 5 obtained the value of $F \_$count of 17.725 with a probability value of 0.000 , because the probability value is smaller than 0.05 then the value of Fhitung obtained is significant. So it can be said that there is a positive and significant influence between cocoa development strategy (X1) and cocoa supply chain (X2) and dummy of sub-districts collectively to the income of cocoa farmer (Y).

Known that there is influence simultaneously then conducted further testing to know the variables that have significant effect. For this purpose, the partial regression coefficient testing is done by using $t$ test statistic. Determination of test results (acceptance / rejection of $\mathrm{H}_{0}$ ) can be done by comparing $\mathrm{t}$ with significance. Test $\mathrm{t}$ or regression coefficient test partially used to determine whether the partially independent variables significantly affect or not to the dependent variable. In this research, partial test is used to find out how far cocoa development strategy (X1), cocoa development strategy (X2), land area (X3) and technology (D) partially influence cocoa farmer income (Y). As for partial analysis results can be seen in the Table 3.

Based on the results summary analysis of data processed above it can be described the following data below:

\section{The effect of cocoa strategy development to farmers' income in Boalemo District}

Based on the analysis obtained elasticity of cocoa development strategy of 0.108 and positive effect on the income of cocoa farmers in Boalemo district means if there is an addition to the strategy variables of cocoa development, the income of cocoa farmers in Boalemo will increase the increase of 0.108 with other factors considered fixed (cateris paribus) . Positive elasticity shows that cocoa development strategy is in rational area because cocoa development strategy can increase cocoa farmer income in Boalemo District.

Then based on t-test value obtained value significance Cocoa development strategy is smaller than probability value 0.05 . So it can be concluded that the strategy of cocoa development has a significant effect on the income of cocoa farmers in Boalemo District, Gorontalo Province. Significant test results show that cocoa development strategy has an effect of (positive / good) increase on farmer's income although it still needs to be improved and improved.

\section{The effect of supply chain to farmers' income in Boalemo District}

Based on the analyzes obtained by the elasticity of the chain of suppliers of a larger size of 0.307 and positively affecting the Revenue in the Boalemo District, the increase in the value chain in the sub-districts of the rural population in Boalemo will increase the magnitude of 0.307 with other factors considered permanent (cateris paribus). Positive production elasticity indicates that the chain of coconut suppliers is on the rear of the supply chain so that it can increase the income of the local government in Boalemo District. 
Then, based on the value of $t$ is obtained, the significance of the supply chain is higher than the probability of 0.05. It can be concluded that the Chain of the supply of cocoa has a significant effect on the income of the local government in the District of the Province of Gontontalo. Significant results indicate that the chain of suppliers will give a good effect to the income of the farmers.

\section{Interpretation of district dummy variables in equations}

The result of the analysis found that probability for Botumoito sub-district (seen from constant) is 0,189 which mean not significant then for District of Tilamuta 0.000 meaning significant and for Dulupi Sub-district 0,006 which means that Sub-district give significant impact for farmer's income.

The results can further be interpreted that the best Sub-District for the ability of development strategy and supply chain in influencing the income of farmers that is in Tilamuta, then followed by Dulupi and after that District Botumoito. This shows that the average farmer in Tilamuta sub-district is able to optimize strategy in the development of good cocoa and supply chain so that the farmer's income becomes better than other sub-districts, then also supported by farmers with good knowledge because of the more optimal training and counseling. Meanwhile, for Botimoito sub-district problems in reluctance aspect of farmers in cocoa cultivation due to previous experience failure in cocoa cultivation.

Compare with the previous research, where the supply chain in the field of agriculture sector has so much influence of some factors, there are technology, farmers counseling, and some of practice for the farmer. But now, it changes by taking place in the wrld economy in recent decades, largely expanded current understanding of the role organization and market structure in a changing competitive market environment. Factors such as globalization and internationalization, increasing competition and focus on the end user, as well as the development of information and communication technology and e-commerce could not affect the modern market structure in the field of supply chain management.

It can be conclude that the best significant impact happen on farmers that living in a Sub-District than in a District. Because it take roles ad the end user of farmers activity of the cocoa commodity.

\section{CONCLUSION AND RECOMMENDATION}

\section{Conclusion}

Partially cocoa commodity development strategy in Boalemo District gives positive influence to farmer's income. Cocoa commodity development strategy implemented by local government of Boalemo District give significant influence to farmer's income. Partially supply chain gives positive effect to cocoa farmer income in Boalemo District. In addition to providing a positive influence, supply chains also have a significant effect on the income of cocoa farmers in Boalemo District.

Simultaneously (simultaneous), development strategies and supply chains provide a positive and significant impact on the income of cocoa farmers in Boalemo District. The significance level of influence for farmers' income tends to be more influenced by supply chain variables. 
Farmers in Tilamuta sub-district are able to optimize strategy in the development of cocoa and supply chain so that the income of farmers is better than other subdistricts, then supported by farmers have experience in good cocoa cultivation system. Botumoito sub-district is problematic in the reluctance aspect of farmers in cultivating cocoa due to previous experience failure in cocoa cultivation.

\section{Recommendations}

The Local Government of Boalemo District of Gorontalo Province needs to evaluate the cocoa development strategy program, because according to the results of the research the cocoa development program has not maximally give a direct impact to the farmers' income sector.

The direct effect on farmers' income in Boalemo District is the availability of the marketing supply chain. Therefore, the Regional Government of Boalemo District is considered necessary in preparing a program that facilitates cocoa farmers in the marketing aspect with the appropriate and feasible price level. The government can intervene in the market by establishing an institution that serves to accommodate farmers' out put (seed cocoa) at the village level with a reasonable price treatment.

To give more leverage to the farmers' income sectors, it is better for local governments to synchronize and collaborate policies between joint and joint development and supply chain strategies. The effect of less than maximal revenue is due to the incomplete program policies, such as the cocoa development strategy program which is not equipped by the mentoring program in the supply chain.

The need for measures taken by the government in order to develop better cocoa, especially in Botumoito sub-district by providing an understanding in the cocoa cultivation system through technical guidance for more intensive cocoa farmers.

\section{REFERENCES}

Arsyad, Lincolin. (2004). Ekonomi Pembangunan. EdisiKeempat. Yogyakarta: STIE YKPN

David, F.R. (2004). "Manajemen Strategis: Konsep. Edisi ketujuh". PT. Prenhallindo, Jakarta

Dradjat, B., Agustian, A., \& Ade, S. (2007). Ekspor dan daya saing kopi biji Indonesia di pasar internasional: Implikasi strategis bagi pengembangan kopi biji organik. Jurnal Penelitian Kopi dan Kakao, 32(2), 139-159

Hussain, safdar, Wasim Ahmed, Ambar Rabnawuz. (2015). Integration and Effective Supply Chain management: A Review of Agriculture in Pakistan and China. https://mpra.ub.uni muenchen.de/70380/MPRA Paper No. 70380, posted 12 May 2016 10:24 UTC. Fujian Agriculture and Forestry University, China, University of Sargodha, Pakistan, PMAS-Arid Agriculture University, Pakistan

Jauch Lawrence R. \& Glueck William F. (1989). Manajemen Dan Strategis Kebijakan Perusahaan. Jakarta: Erlangga

Malholtra, neena, Deepika Kumari. (2018). Trade, Investment and Economic Growth in India and China. Jurnal Perspektif Pembiayaan dan Pembangunan Daerah Vol. 5. No. 4, April - June 2018. ISSN: 2338-4603 (print); 2355-8520 (online).

Nazarro, Concetta, Giuseppe marotta, Marcello Stanco. (2016). Shared value and responsibility in agriculture: the short supply chain model. Rivista di Economia Agraria, Anno LXXI, n. 1 (Supplemento), (2016). Firenze University Press 
Scoones, Ian, Blasio Mavedzenge, Felix Murimbarimba, Chrispen Sukume. (2016). Tobacco, Contract farming, and Agrarian Change in Zimbabwe. wileyonlinelibrary.com/journal/joac. J Agrar Change. 2018;18:22-42

Sunil Chopra, Peter Meindl, (2010), Supply Chain Management, 4th Edition, Pearson Wisner, Tan, Leong, (2012), Principles of Supply Chain Management, Cengage Learning 